\title{
COMPENSATORY GRANT IN POLISH RURAL COMMUNES - MODIFICATION CONCEPT AND ITS IMPACT ON FINANCES OF COMMUNES
}

\author{
Jaroslaw OLEJNICZAK, Ph.D. \\ Department of Finance, Faculty of Economic Sciences \\ Wroclaw University of Economics \\ Komandorska street 118/120, 53-345 Wroclaw, Poland \\ E-mail: jaroslaw.olejniczak@ue.wroc.pl
}

\begin{abstract}
Annotation
The aim of this paper it to present the results of research on the scale of the compensatory mechanism in Polish rural communes in the context of their differentiation by the development level described by means of the taxonomic measure of development by Hellwig. The following research questions were formulated: how significant is compensatory grant for rural communes from the viewpoint of their income and current expenses, should its present beneficiaries receive funds from the viewpoint of their development level as a criterion for awarding grants, what financial effects might the modification of the list of beneficiaries cause. A division of communes into four groups in terms of the designated development level and four groups in terms of income level per resident was used for the analysis. The analysis of the basic taxable income ratio per capita in the period 2009-2011 demonstrates the presence of significant and permanent differences between individual Polish regions. The largest number of communes with high BTI ratio per capita occurs in western Poland. Based on the research it can be stated that compensatory grant significantly contributes to the balancing of current expenses with current income, in particular in communes in eastern Polish voivodeships. The self-financing ratios adjusted by grant are obtained mainly by communes with a high development level. The number of these communes was not affected by the financial effects of the 2008-2010 crisis. With the assumed division of communes into three groups with diverse granting level, it can be stated that grant liquidation for developed communes would concern merely 5.5\% of the entire compensatory grant for rural communes in 2011. At the same time, it needs to be observed that this would mean disturbing the financial sustainability of certain communes. The greatest decrease in income per resident would be experienced by communes in the Lower Silesian, Masovian, Greater Poland and Silesian voivodeships. Based on the conducted research, it must be stated that accounting for the development level of communes while building a new funds redistribution model brings along the necessity to pay attention to ensuring budget stability in the communes which, as a result of grant restriction, might lose the self-financing capacity and face a current deficit.
\end{abstract}

\section{Key words}

local government finance, rural development, financial indicators

JEL classification: $H 71,018$

\section{Introduction}

Since the new model of horizontal solidarity functioning between local government units was adopted by the Act of 2003 (the Act of 2003 on income of local government units), the dispute about the correctness of its shape has been increasing. In 2012 attempts to make changes to this mechanism were made (parliamentary papers 230 and 19 of 2012) but they did not come into force. The problem of optimisation the compensatory mechanism comes down to two basic issues. Firstly, to determining the actual demand for the compensatory mechanism, and secondly, to ensuring the optimum redistribution method. According to the public finance theory (Patrzałek, 1998, p. 67), the grant mechanism for local government units should play the regulatory (compensatory) function as well as 
the dynamising (stimulating) function. From the viewpoint of the analysed scope of overall grant, it is obvious that the former function is most related to the horizontal redistribution mechanism. Although it is particularly associated with eliminating disproportions in supporting budgets of local government units arising from different financial potentials of these units, it refers more broadly to maintaining a sustainable structure of the performed social and educational tasks in terms of territory (Patrzałek, 1998, p. 68; Kopyściański, 2011). Hence, the major goal of the compensatory mechanism should be equalising the level (scope) of the provided public services in all local governments. This will mean achieving a relatively uniform development level in the financial, social as well as cultural and educational dimension by communes. The present system is based on the assumption that is the scale of income per resident that determines obtaining compensatory transfers by communes. The aim of this paper is to indicate the possibilities to restrict the compensatory mechanism based on the development level criterion and the financial effects for communes arising from the proposed modification.

\section{Aim and methods}

The aim of this paper it to present the results of research on the scale of the compensatory mechanism in Polish rural communes in the context of their differentiation by the development level described by means of the taxonomic measure of development by Hellwig. The conducted analysis should allow answers to the following research questions: how significant is compensatory grant for rural communes from the viewpoint of their income and current expenses, should its present beneficiaries receive funds from the viewpoint of their development level as a grant, should its present beneficiaries receive funds from the viewpoint of their development level as a criterion for awarding grants, what financial effects might the modification to the list of beneficiaries cause.

The results of earlier research, conducted by the author, on diversity of the development level of rural communes in Poland against their basic taxable income were used in the analysis (Olejniczak 2013; Olejniczak 2012). In accordance with the research conducted earlier, it was assumed that BTI ratios per resident - reflecting the income level (and at the same time constituting a compensatory mechanism criterion), as values that are "delayed" in time, would be determined with a two years' delay with respect to development level ratios. Commune development level ratios, in turn, were calculated with the use of a procedure involving the analysis and selection of the variables from 2009, 2010, 2011 available in the Local Data Bank of CSO, which reflect the development level of communes. Measures of development were determined for individual communes in accordance with the Hellwig's method based on the obtained ratios (Hellwig, 1968; Sthral, 1998). Variability index $V_{j}$ was computed for the selected variables by the formula (1) with the critical value of the coefficient $V^{*}$ $\leq 0.1$. The absolute values of the indices for all features exceeded the above level and hence were all subject to further analysis.

$V_{j}=\frac{S_{j}}{\bar{x}_{j}}$

where:

$V_{j}$ - variation coefficient for $j$-variable

$S_{j}$ - standard deviation for $j$-variable, computed according to (2):

$S_{j}=\sqrt{n^{-1} \sum_{i=1}^{n}\left(x_{i j}-\bar{x}_{j}\right)^{2}}$

$\bar{x}_{j}$ - arithmetic mean for $j$-variable

Subsequently, Pearson correlation coefficient matrix was built (3). 


$$
r_{x y}=\frac{\sum_{i=1}^{n}\left(x_{j}-\bar{x}\right)\left(y_{j}-\bar{y}\right)}{\sqrt{\sum_{i=1}^{n}\left(x_{j}-\bar{x}\right)^{2} \sum_{i=1}^{n}\left(y_{j}-\bar{y}\right)^{2}}}
$$

where: $r_{x y}$ - Pearson's correlation coefficient, $X, Y$ - measurable statistical features,

$\bar{x}, \bar{y}$ - arithmetic mean, features $X$ and $Y$, respectively.

It was assumed that the features which show high correlation, whose correlation coefficient satisfies the condition $\left|\mathrm{r}_{\mathrm{xy}}\right| \geq r^{*}$ in relation to the critical value $r^{*}=|0.75|$ would not be allowed for in the further study. Thus, matrix $\mathrm{X}$ was obtained, with successive lines corresponding to particular local government units and columns - to the values of the individual features for the following entities.

$$
X=\left[\begin{array}{cccc}
x_{11} & x_{12} & \ldots & x_{1 m} \\
x_{21} & x_{22} & \ldots & x_{2 m} \\
\ldots & \ldots & \ldots & \ldots \\
x_{n 1} & x_{n 2} & \ldots & x_{n m}
\end{array}\right]
$$

where $x_{i j}$ - stands for the value of $j$-feature for $i$-object $(i=1,2, \ldots, n ; j=1,2, \ldots, m)$. In order to unify the variables, the features were standardised by the formula:

$$
z_{i j}=\frac{\left(x_{i j}-\bar{x}_{j}\right)}{S_{j}}
$$

thus obtaining a matrix of standardised values, where $z_{i j}$ stands for the value of $j$-feature for $i$-object $(i$ $=1,2, \ldots, n ; j=1,2, \ldots, m)$.

$$
Z=\left[\begin{array}{cccc}
z_{11} & z_{12} & \ldots & z_{1 m} \\
z_{21} & z_{22} & \ldots & z_{2 m} \\
\ldots & \ldots & \ldots & \ldots \\
z_{n 1} & z_{n 2} & \ldots & z_{n m}
\end{array}\right]
$$

Based on the above data, development pattern with standardised coordinates was determined in accordance with the Hellwig's taxonomic method of development pattern, including the division into stimulants and destimulants. Subsequently, the development measure for each municipality was computed by the formula:

$d_{i}=1-\frac{D_{i 0}}{D_{0}}$

where:

$$
\begin{aligned}
D_{i 0} & =\sqrt{\sum_{i=1}^{m}\left(z_{i j}-z_{0}\right)^{2}} \\
D_{0} & =\bar{D}_{0}+2 S_{0} \\
\bar{D}_{0} & =n^{-1} \sum_{i=1}^{n} D_{i 0} \\
S_{0} & =\sqrt{n^{-1} \sum_{i=1}^{n}\left(D_{i 0}-\bar{D}_{0}\right)^{2}}
\end{aligned}
$$

By the above means synthetic indicators in the years 2009, 2010 and 2011 for each of the rural municipalities in Lower Silesian Voivodeship were determined. Afterward, the municipalities 
were divided into four groups. The municipalities of a high development level (type A) included the entities with the development index higher than the mean plus the standard deviation. The municipalities of a higher than medium development level (type B1) included the entities with the index falling within the range of mean to mean plus standard deviation. The third group municipalities of a lower than medium development level (type B2) included the entities with the index falling within the range of mean to mean minus standard deviation. The last group comprised the municipalities of a low development level (type C), where the index achieved was lower than the mean minus the standard deviation.

The other of the components is the analysis of the grant amount per resident in the examined communes, the relation of compensatory grant to the operating result and the self-financing ratio from years 2009, 2010, 2011. The operating result is the difference between current income and current expenses of a commune. Its positive value reflects the commune's capacity to engage in additional projects, whereas its negative value indicates a shortage of funds relative to objectives and incapacity to take investment actions. The analysis of the impact of the current income decrease by the grant amount on the operating result and the commune self-financing ratio will enable the assessment of this grant's significance for the current sustainability of communes. At the same time, comparing the development level of communes with the obtained ratios will enable the adoption of another perspective when assessing the reasonability of applying compensatory grant. The source of the data is databases of the Ministry of Finance regarding the implementation of LGUs' budgets, the data from the Local Data Bank of CSO. The impact of the proposed solution on the change of the redistribution scale through the budget system will also be analysed.

\section{Results of the research}

Due to high diversity of income in communes, the new Act of 2004 introduced an advanced compensatory system aimed at protecting local government units that have a low income potential. The differences in income are subject to the compensatory mechanism that is progressive in nature. The compensatory part of the overall grant for communes is composed of the basic amount and the supplementary amount. With respect to the basic amount, it is significant to determine the amount of the basic taxable income (BTI) per resident in accordance with the Act (the Act of 2003 on income of local government units, Article 20). Changes regarding the compensation scale occurred in this area in the successive years. In general, the basic amount is received by the communes where taxable income per resident $(\mathrm{G})$ is lower than $92 \%$ of the average taxable income per resident of the country $(\mathrm{Gg})$.

$$
\begin{array}{ll}
\mathrm{G} \leq 40 \% \mathrm{Gg} & \mathrm{Sg}=\mathrm{L} *[0,99 *(0,4 * \mathrm{Gg}-\mathrm{G})+41,97] \\
40 \% \mathrm{Gg}<\mathrm{G} \leq 75 \% \mathrm{Gg} & \mathrm{Sg}=\mathrm{L} *[0,83 *(0,75 * \mathrm{Gg}-\mathrm{G})+12,92] \\
75 \% \mathrm{G}<\mathrm{G} \leq 92 \% \mathrm{Gg} & \mathrm{Sg}=\mathrm{L} *[0,76 *(0,925 * \mathrm{Gg}-\mathrm{G})]
\end{array}
$$

The other component of the compensatory part, the supplementary amount, is received by communes with a lower population density than the average population density in Poland. This amount is calculated by multiplying $17 \%$ of the Gg ratio, the number of the commune's residents and the ratio being the quotient of the difference between the average population density in Poland and the average population density in the community to the average population density in Poland. The possibility to obtain the mentioned supplementary amount is restricted - it is not allocated for the communes for which the $\mathrm{G}$ income ratio is higher than $150 \%$ of the Gg ratio in Poland. In such a situation, the supplementary amount calculated in the said manner increases the compensatory part of the overall grant for communes.

The compensatory part for communes is determined as the total amount of the payments made by the communes whose $\mathrm{G}$ ratio exceeds $150 \%$ of the $\mathrm{Gg}$ ratio and the said supplementary amounts. This part is received by communes for the purpose of compensating differences in income, if any, due to the introduction of changes to the objectives financing system. 
Tab. 1: Number of municipalities in the individual categories BTI per capita in the years 2009, 2010 and 2011 by voivodeships

\begin{tabular}{|c|c|c|c|c|c|c|c|c|c|c|c|c|c|c|c|}
\hline & \multicolumn{3}{|c|}{$\begin{array}{l}\infty \\
0 \\
0 \\
0 \\
i \\
\hat{0} \\
0\end{array}$} & \multicolumn{3}{|c|}{ 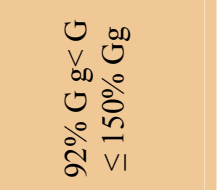 } & \multicolumn{3}{|c|}{ 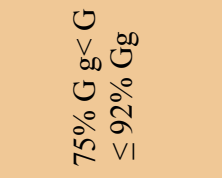 } & \multicolumn{3}{|c|}{ 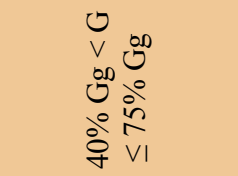 } & \multicolumn{3}{|c|}{ 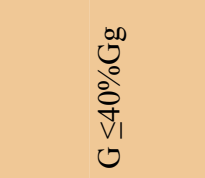 } \\
\hline & '09 & $' 10$ & '11 & ‘09 & $' 10$ & ' 11 & '09 & $' 10$ & ' 11 & '09 & $' 10$ & ' 11 & '09 & $' 10$ & ' 11 \\
\hline Lower Silesian & 7 & 6 & 6 & 20 & 19 & 22 & 19 & 16 & 14 & 32 & 37 & 36 & 0 & 0 & 0 \\
\hline Kuyavian-Pomeranian & 3 & 3 & 3 & 8 & 8 & 7 & 12 & 10 & 8 & 66 & 65 & 69 & 3 & 6 & 5 \\
\hline Lublin & 1 & 1 & 1 & 3 & 3 & 4 & 5 & 6 & 6 & 123 & 91 & 99 & 39 & 70 & 61 \\
\hline Lubusz & 1 & 1 & 1 & 11 & 8 & 11 & 5 & 7 & 9 & 24 & 25 & 20 & 0 & 0 & 0 \\
\hline Łódź & 5 & 5 & 5 & 8 & 9 & 12 & 16 & 15 & 16 & 82 & 79 & 81 & 22 & 25 & 19 \\
\hline Lesser Poland & 0 & 0 & 0 & 6 & 6 & 6 & 3 & 3 & 4 & 69 & 69 & 74 & 43 & 43 & 37 \\
\hline Msovian & 13 & 14 & 14 & 16 & 14 & 13 & 20 & 20 & 21 & 139 & 136 & 140 & 41 & 45 & 41 \\
\hline Opolskie & 1 & 1 & 2 & 5 & 5 & 4 & 9 & 9 & 13 & 20 & 20 & 16 & 1 & 1 & 1 \\
\hline Podkarpackie & 1 & 1 & 1 & 2 & 2 & 5 & 4 & 3 & 6 & 63 & 66 & 78 & 39 & 37 & 19 \\
\hline Podlaskie & 2 & 2 & 1 & 7 & 9 & 8 & 6 & 3 & 7 & 59 & 56 & 56 & 4 & 8 & 6 \\
\hline Pomeranian & 5 & 6 & 5 & 11 & 9 & 10 & 11 & 7 & 10 & 53 & 59 & 55 & 1 & 0 & 1 \\
\hline Silesian & 8 & 8 & 7 & 19 & 23 & 24 & 20 & 18 & 20 & 48 & 45 & 44 & 1 & 2 & 1 \\
\hline Świętokrzyskie & 1 & 1 & 1 & 2 & 2 & 2 & 2 & 3 & 3 & 45 & 40 & 47 & 21 & 25 & 18 \\
\hline Warmian-Masurian & 0 & 0 & 0 & 9 & 9 & 9 & 12 & 9 & 7 & 44 & 43 & 47 & 2 & 6 & 4 \\
\hline Greater Poland & 6 & 6 & 5 & 17 & 17 & 18 & 15 & 12 & 16 & 72 & 72 & 71 & 7 & 10 & 7 \\
\hline West Pomeranian & 7 & 8 & 7 & 6 & 6 & 8 & 10 & 6 & 8 & 27 & 30 & 27 & 0 & 0 & 0 \\
\hline
\end{tabular}

Source: Own work based on the results of the study and Ministry of Finance data

The analysis (table 1) of the BTI ratio per capita in the period 2009-2011 that determined the amount of grant proves the existence of significant permanent differences between individual Polish regions. The majority of communes with high BTI ratios per capita are located in western Poland (the Lower Silesian, Pomeranian, Silesian and West Pomeranian voivodeships). Along with the decreasing ratio, the number of communes in eastern Polish voivodeships increases. The greatest diversity is noticeable, however, in the case of the Masovian voivodeship, where the number of communes with a high and low BTI per capita is balanced. It needs to be emphasised that no communes with the lowest ratios are to be found in several voivodeships. This reflects the significant diversity in the income potential of communes and exposes the major reason for applying the compensatory mechanism in the present form.

From the viewpoint of the efficiency of providing financial support for communes, the mentioned amount of the current budget balance (the operating result) is a significant criterion. This balance shows how a commune handles financing all its most important objectives. Surplus is usually a beneficial situation indicating the capacity to extend the scale of the pursued objectives, financing new projects or covering borrowings and loans from previous years. Deficit proves that the commune does not manage to finance its current activities. Excluding the amount of the received grant from the calculation should demonstrate the degree to which it affects activities taken by communes.

The results of the analysis (table 2) indicate an extremely significant impact of compensatory grant on the balancing of current expenses with current income, particularly in the communes in eastern Polish voivodeships. However, the income adjustment by grant results in a considerable decrease in the number of surplus budgets also in other voivodeships (e.g. Lower Silesian - by a half, Greater Poland - by $2 / 3$ ). To conclude, the results of the research prove the high significance of compensatory grant in the present financing system of rural communes. This means that changes in the redistribution scale should be made with the account for negative effects of reducing communes' income. 
Tab. 2: Number of municipalities in the years 2009, 2010 and 2011 by voivodeships - with surplus or deficit in budget balance with and without equalization grant

\begin{tabular}{|c|c|c|c|c|c|c|c|c|c|c|c|c|}
\hline & \multicolumn{6}{|c|}{ Number of communes with surplus } & \multicolumn{6}{|c|}{ Number of communes with deficit } \\
\hline & \multicolumn{3}{|c|}{ with grant } & \multicolumn{3}{|c|}{ without grant } & \multicolumn{3}{|c|}{ with grant } & \multicolumn{3}{|c|}{ without grant } \\
\hline & ‘09 & ' 10 & '11 & '09 & ' 10 & '11 & ‘09 & ‘ 10 & '11 & '09 & ' 10 & '11 \\
\hline Lower Silesian & 63 & 57 & 68 & 29 & 23 & 36 & 15 & 21 & 10 & 49 & 55 & 42 \\
\hline Kuyavian-Pomeranian & 91 & 84 & 90 & 24 & 24 & 20 & 1 & 8 & 2 & 68 & 68 & 72 \\
\hline Lublin & 170 & 147 & 162 & 12 & 11 & 12 & 1 & 24 & 9 & 159 & 160 & 159 \\
\hline Lubusz & 37 & 35 & 40 & 18 & 10 & 11 & 4 & 6 & 1 & 23 & 31 & 30 \\
\hline Łódź & 131 & 123 & 128 & 32 & 29 & 25 & 2 & 10 & 5 & 101 & 104 & 108 \\
\hline Lesser Poland & 115 & 115 & 113 & 20 & 16 & 17 & 6 & 6 & 8 & 101 & 105 & 104 \\
\hline Msovian & 225 & 218 & 223 & 65 & 50 & 50 & 4 & 11 & 6 & 164 & 179 & 179 \\
\hline Opolskie & 33 & 27 & 34 & 7 & 7 & 11 & 3 & 9 & 2 & 29 & 29 & 25 \\
\hline Podkarpackie & 101 & 89 & 105 & 19 & 12 & 11 & 8 & 21 & 5 & 90 & 98 & 99 \\
\hline Podlaskie & 78 & 64 & 69 & 11 & 14 & 11 & 0 & 14 & 9 & 67 & 64 & 67 \\
\hline Pomeranian & 77 & 72 & 75 & 29 & 27 & 25 & 4 & 9 & 6 & 52 & 54 & 56 \\
\hline Silesian & 90 & 85 & 90 & 48 & 46 & 48 & 6 & 11 & 6 & 48 & 50 & 48 \\
\hline Świętokrzyskie & 69 & 61 & 67 & 10 & 9 & 7 & 2 & 10 & 4 & 61 & 62 & 64 \\
\hline Warmian-Masurian & 60 & 49 & 54 & 9 & 9 & 8 & 7 & 18 & 13 & 58 & 58 & 59 \\
\hline Greater Poland & 114 & 106 & 113 & 35 & 33 & 35 & 3 & 11 & 4 & 82 & 84 & 82 \\
\hline West Pomeranian & 46 & 34 & 41 & 18 & 13 & 18 & 4 & 16 & 9 & 32 & 37 & 32 \\
\hline
\end{tabular}

At the next stage of the research, the proposed division of communes into A, B1, B2, C categories was combined with the amount of the self-financing ratio of communes adjusted by the grant amount (table 3). It illustrates the degree to which a commune might finance projects contributing to its development with its own funds. The higher the relation, the lower the risk of losing financial liquidity due to excessive costs of debt service; yet its high value might also prove the low level of the implemented projects compared to its capacities. The adjustment by the grant amount enables the assessment of the impact of this income source on the capacity of the examined communes to selffinance projects.

Tab. 3: Number of municipalities in the years 2009, 2010 and 2011 by voivodeships - with surplus or deficit in budget balance with and without equalization grant

\begin{tabular}{|c|c|c|c|c|c|c|c|c|c|c|c|c|c|}
\hline & \multirow[t]{2}{*}{ Total } & \multicolumn{3}{|c|}{ Type A } & \multicolumn{3}{|c|}{ Type B1 } & \multicolumn{3}{|c|}{ Type B2 } & \multicolumn{3}{|c|}{ Type C } \\
\hline & & '09 & $، 10$ & '11 & ‘09 & ' 10 & $' 11$ & '09 & ' 10 & $' 11$ & ‘09 & ‘ 10 & $' 11$ \\
\hline Lower Silesian & 78 & 7 & 9 & 5 & 30 & 34 & 23 & 12 & 12 & 14 & 0 & 0 & 0 \\
\hline Kuyavian-Pomeranian & 92 & 4 & 3 & 3 & 21 & 17 & 18 & 37 & 38 & 46 & 6 & 10 & 5 \\
\hline Lublin & 171 & 1 & 1 & 3 & 25 & 28 & 26 & 99 & 108 & 107 & 34 & 23 & 23 \\
\hline Lubusz & 41 & 1 & 4 & 3 & 10 & 9 & 12 & 12 & 18 & 15 & 0 & 0 & 0 \\
\hline Łódź & 133 & 2 & 4 & 1 & 31 & 35 & 41 & 61 & 59 & 62 & 7 & 6 & 4 \\
\hline Lesser Poland & 121 & 7 & 2 & 8 & 38 & 38 & 33 & 47 & 52 & 50 & 9 & 13 & 13 \\
\hline Msovian & 229 & 1 & 3 & 1 & 24 & 37 & 32 & 113 & 112 & 111 & 26 & 27 & 35 \\
\hline Opolskie & 36 & 3 & 6 & 3 & 12 & 13 & 10 & 13 & 10 & 11 & 1 & 0 & 1 \\
\hline Podkarpackie & 109 & 1 & 1 & 1 & 21 & 17 & 20 & 58 & 70 & 69 & 10 & 9 & 8 \\
\hline Podlaskie & 78 & 2 & 1 & 2 & 6 & 8 & 9 & 38 & 38 & 34 & 21 & 17 & 22 \\
\hline Pomeranian & 81 & 3 & 0 & 1 & 28 & 23 & 26 & 20 & 29 & 26 & 1 & 2 & 3 \\
\hline Silesian & 96 & 6 & 8 & 6 & 34 & 32 & 34 & 8 & 10 & 8 & 0 & 0 & 0 \\
\hline Świętokrzyskie & 71 & 1 & 1 & 0 & 10 & 8 & 14 & 43 & 48 & 43 & 7 & 5 & 7 \\
\hline Warmian-Masurian & 67 & 1 & 1 & 2 & 8 & 9 & 7 & 33 & 33 & 32 & 16 & 15 & 18 \\
\hline Greater Poland & 117 & 14 & 14 & 15 & 15 & 14 & 12 & 6 & 5 & 8 & 0 & 0 & 0 \\
\hline West Pomeranian & 50 & 10 & 8 & 11 & 7 & 3 & 6 & 1 & 2 & 1 & 0 & 0 & 0 \\
\hline
\end{tabular}


The results of the analysis prove unambiguously that the positive "adjusted" self-financing ratios are achieved mainly by communes characterised by a high development level. The number of these communes was not affected by the financial effects of the 2008-2010 crisis since their number in individual voivodeships did not change significantly over the examined period. What can be observed, however, is analogies in the distribution of communes with respect to the previous ratio. Normally, communes from western Polish voivodeships are more developed, have better income ratios per resident and much more frequently achieve positive self-financing ratios. It needs to be noticed that the division line runs usually between the communes with the development ratio qualified to B1 and B2 groups. This means that it could prove reasonable in practice to include the development level ratio as the criterion for obtaining compensatory grant

\section{Conclusions - Financial effects of changing the financing system of rural communes on a system accounting for diversity of development levels of communes.}

With the use of the 2011 data as the basis for calculation and with the assumption that the compensatory mechanism should divide communes into four categories distinguished based on the development level $(\mathrm{A}, \mathrm{B} 1, \mathrm{~B} 2, \mathrm{C})$ and the BTI amount per capita compared to the country's average, the following were distinguished: communes with very high both ratios - not covered by compensation and paying in funds for the poor, neutral communes (with acceptable income and a good development level), communes requiring partial support (due to the development level being lower than the average or a significant shortage of funds), and communes with a high demand for support (with a low development level and relatively poor income).

Tab. 4: Estimated number of municipalities in the years 2011 by voivodeships after proposed change in grant system

\begin{tabular}{|c|c|c|c|c|c|c|c|c|c|c|c|c|c|c|c|c|c|c|c|}
\hline 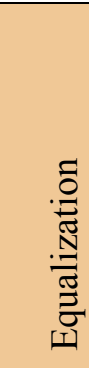 & 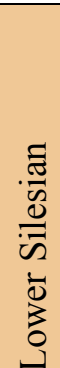 & 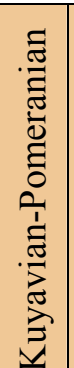 & $\begin{array}{l}: \\
\frac{\Xi}{3} \\
\end{array}$ & 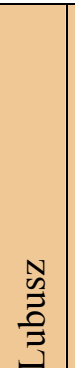 & $\frac{v}{0}$ & 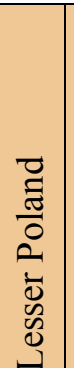 & 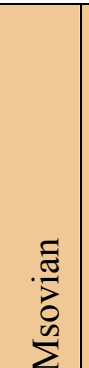 & $\begin{array}{l}\frac{0}{\frac{\pi}{v}} \\
\frac{\vec{v}}{0} \\
\frac{0}{2}\end{array}$ & 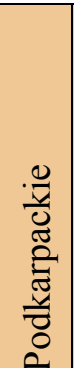 & $\begin{array}{l}\frac{0}{\tilde{y}} \\
\frac{\pi}{\tilde{z}} \\
\frac{\pi}{0}\end{array}$ & 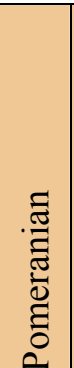 & 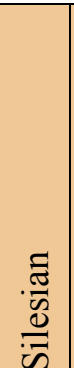 & 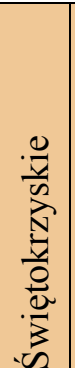 & 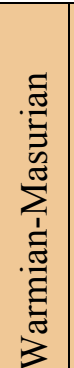 & 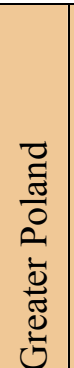 & 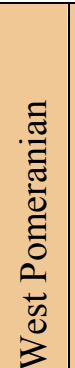 & 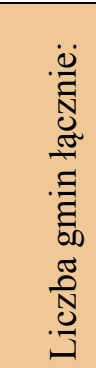 & $\begin{array}{l}\ddot{z} \\
\text { a } \\
\Xi \\
\Xi \\
\Xi \\
\Xi \\
\Xi \\
\Xi\end{array}$ & ن⿺辶 \\
\hline No & 35 & 12 & 7 & 14 & 18 & 15 & 28 & 10 & 6 & 8 & 16 & 40 & 2 & 9 & 24 & 17 & 261 & 210,4 & 0,05 \\
\hline $\begin{array}{l}\text { Part- } \\
\text { ly }\end{array}$ & 43 & 71 & 95 & 27 & 95 & 71 & 141 & 24 & 79 & 45 & 62 & 55 & 48 & 38 & 87 & 33 & 1014 & 2636,4 & 0,68 \\
\hline Full & 0 & 9 & 69 & 0 & 20 & 35 & 60 & 2 & 24 & 25 & 3 & 1 & 21 & 20 & 6 & 0 & 295 & 103,5 & 0,27 \\
\hline
\end{tabular}

When taking into consideration only the abandoning of financing the best communes (the first two categories) with grant, it would have been possible to obtain as much as PLN 210,394,000 in 2011, which constituted circa $5.5 \%$ of the overall compensatory grant for rural communes. At the same time, it needs to be noticed that this would mean disturbing the financial sustainability of certain communes from the viewpoint of the analysed ratios. The consequences of such a solution would be diverse in individual voivodeships. The greatest decrease in income per resident would be experienced by the Lower Silesian, Masovian, Greater Poland and Silesian voivodeships. It should be observed that the change in the redistribution scope would also enable shifting some funds from the pool currently transferred to communes with an average development and income level, which receive merely $26.7 \%$ of grant at present. 


\section{Literature}

[1] HELLWIG Z. Zastosowanie metody taksonomicznej do typologicznego podziału krajów ze względu na poziom rozwoju oraz zasoby i strukture wykwalifikowanych kadr, Przegląd Statystyczny, 15.4.1968.

[2] KOPYŚCIAŃSKI T. Selection criteria of strategic goals for local governments. Argumenta Oeconomica,No. 2 (27) 2011, p. 15-36.

[3] OLEJNICZAK J. Wskaźnik podstawowych dochodów podatkowych na mieszkańca a poziom rozwoju gmin - na przykładzie województwa dolnośląskiego. In Finanse Publiczne, ed. Sokołowski J., Sosnowski M., Żabiński A., Wydawnictwo Uniwersytetu Ekonomicznego we Wrocławiu, Wrocław, 2012.

[3] OLEJNICZAK J. The Development Level of Rural Municipalities in Lower Silesian Voivodeship in View of Their Income Structure. In 15th International Colloquium on Regional Sciences. Conference Proceedings. Brno: Masaryk University, 2012. ISBN 978-80-210-5875-0.

[4] PATRZAŁEK L. Finanse samorzadowe, Wydawnictwo Akademii Ekonomicznej we Wrocławiu, Wrocław, 1998.

[5] Taksonomia struktur $w$ badaniach regionalnych, red. D. Strahl, Wydawnictwo Akademii Ekonomicznej we Wrocławiu im. Oskara Langego, Wrocław, 1998.

[6] The Act of 13 November 2003 on income of local government units,Dz.U. 2003 nr 203 poz. 1966. 